\title{
Acute exacerbation of cold agglutinin disease during operation
}

\author{
Jinyoung Jeong ${ }^{1}$, Hye Kyoung Lee ${ }^{2}$, Eun-Su Choi ${ }^{3}$, and Wonsik $\mathrm{Ahn}^{4}$ \\ Department of Anesthesiology and Pain Medicine, ${ }^{1}$ Seoul National University Hospital, Seoul, ${ }^{2}$ Hallym University Sacred Heart \\ Hospital, Anyang, ${ }^{3}$ Seoul National University Bundang Hospital, Seongnam, ${ }^{4}$ Seoul National University Dental Hospital, Seoul, Korea
}

Cold agglutinin, an autoantibody that combines with the red blood cell (RBC) carbohydrate antigen, is known to trigger hemolysis with agglutination at temperatures of $0-4^{\circ} \mathrm{C}[1]$. Cold agglutinin combined with RBC in a peripheral body exposed to a cold environment returns to the center of the body and combines with the complement; these processes form the mechanism for chronic cold agglutinin disease. However, these processes can result in acute aggravation due to stimuli such as infection and trauma [2]. The authors experienced hemolysis during an operation in a patient with cold agglutinin disease although his temperature was maintained above $35.6^{\circ} \mathrm{C}$.

A 67-year-old male patient diagnosed with bladder cancer was scheduled for a radical cystectomy with ileal conduit formation. He had been diagnosed with idiopathic cold agglutinin disease 20 years earlier. Hematologic conditions were stable without any medication. Hemoglobin was measured as $6.9 \mathrm{~g} / \mathrm{dl} 2$ days prior to the surgery. After 3 units of leukocyte-depleted RBC were transfused, the hemoglobin level increased to $9.9 \mathrm{~g} / \mathrm{dl}$. The cold agglutinin titer was $1: 8192$ and total bilirubin was $2.9 \mathrm{~g} / \mathrm{dl}$ before the surgery.

On the day of the surgery, the temperature of the operation room was raised to its maximum of $30^{\circ} \mathrm{C}$. An esophageal stethoscope with a temperature probe was inserted after induction to read the core body temperature (BT), and a skin temperature probe was attached to the forehead to read the peripheral BT. The body of the patient, excluding the site of surgery, was covered in cotton blankets, and 2 air warmers were used. A normothermic $\left(37^{\circ} \mathrm{C}\right)$ intravenous fluid administration set was used to elevate the temperature of all fluids. The inhalational gas supplied to the patient was set at $37^{\circ} \mathrm{C}$ using a heated circuit.
The core $\mathrm{BT}$ of the patient was $37^{\circ} \mathrm{C}$ and his peripheral BT was $35.6^{\circ} \mathrm{C}$ during the surgery.

It was observed that the urine had a strong brown color [3], and at 60 minutes after anesthesia (30 minutes after the operation), blood tests showed hemoglobin at $11.0 \mathrm{~g} / \mathrm{dl}$, lactate dehydrogenase $(\mathrm{LDH})$ at $494 \mathrm{IU} / \mathrm{L}$, total bilirubin at $5.4 \mathrm{~g} / \mathrm{dl}$, and direct bilirubin at $2.1 \mathrm{~g} / \mathrm{dl}$. We decided that postoperative plasmapheresis was more appropriate than intraoperative plasmapheresis [4]. The estimated blood loss during the 600 minute surgery was $2800 \mathrm{ml}$, infused fluid HES $500 \mathrm{ml}$, and normal saline $4800 \mathrm{ml}$. Leukocyte-depleted RBC 6-units were transfused.

Therapeutic plasmapheresis was executed for 180 minutes in the intensive care unit. The patient's blood was extracted through an arterial line and reinfused through a central venous line. Both lines were passed through fluid warmers. Therapeutic plasmapheresis was completed without any complications.

The test results were as shown in Table 1. The hemoglobin level was stable without any significant decrease; therefore, the patient was transferred to the general ward on postoperative day 5 (POD\#5). During the intensive care unit (ICU) stay, the temperature taken from the arm pit was above $38^{\circ} \mathrm{C}$ for the first 2 days and remained at $37-38^{\circ} \mathrm{C}$ until the fifth day. After transfer to the general ward, RBC 1 unit was transfused on each of the following days: POD\#8, POD\#10, POD\#13, and POD\#15. The temperature taken from the arm pit remained at $38^{\circ} \mathrm{C}$. The patient was discharged on POD\#16 with a hemoglobin level of 8.9 $\mathrm{g} / \mathrm{dl}$, and a month after the surgery ( 2 weeks after discharge), the hemoglobin measured at ambulatory care was $7.4 \mathrm{~g} / \mathrm{dl}$. There were no complications afterwards.

In this case, although the cold agglutinin antibody number

Corresponding author: Wonsik Ahn, M.D., Department of Anesthesiology and Pain Medicine, Seoul National University Dental Hospital, 101, Daehak-ro, Jongno-gu, Seoul 110-744, Korea. Tel: 82-2-2072-3087, Fax: 82-2-766-3087, E-mail: aws@snu.ac.kr

(c) This is an open-access article distributed under the terms of the Creative Commons Attribution Non-Commercial License (http:// creativecommons.org/licenses/by-nc/3.0/), which permits unrestricted non-commercial use, distribution, and reproduction in any medium, provided the original work is properly cited. 
Table 1. Changes in Laboratory Findings

\begin{tabular}{|c|c|c|c|c|c|c|}
\hline Time & $\mathrm{Hb}^{*}(\mathrm{~g} / \mathrm{dl})$ & $\begin{array}{l}\text { Total bilirubin } \\
(\mathrm{mg} / \mathrm{dl})\end{array}$ & $\begin{array}{l}\text { Direct bilirubin } \\
\quad(\mathrm{mg} / \mathrm{dl})\end{array}$ & $\begin{array}{l}\mathrm{LDH}^{\dagger} \\
(\mathrm{IU} / \mathrm{L})\end{array}$ & $\begin{array}{l}\text { Cold agglutinin } \\
\text { titer }\end{array}$ & $\begin{array}{c}\text { Transfused } \\
\mathrm{RBC}^{\ddagger} \text { (packs) }\end{array}$ \\
\hline Preoperative & 9.9 & 2.9 & & & $1: 8192$ & 3 \\
\hline $30 \mathrm{~min}$ & 11.0 & 5.4 & 2.1 & 494 & & \\
\hline $120 \mathrm{~min}$ & 7.9 & 6.0 & - & 387 & & \\
\hline $240 \mathrm{~min}$ & 10.5 & 7.7 & - & 343 & & 2 \\
\hline $420 \mathrm{~min}$ & 8.7 & - & - & 237 & & 1 \\
\hline $540 \mathrm{~min}$ & 12.0 & 10.5 & 5.6 & - & & 3 \\
\hline $600 \mathrm{~min}$ & - & 13.1 & 6.0 & 395 & & \\
\hline Post-plasmaphresis & 10.7 & - & - & - & - & - \\
\hline POD\# $1^{\S}$ & 9.6 & 8.4 & 3.5 & 165 & $1: 2048$ & - \\
\hline POD\#2 & 6.6 & 16.9 & 10.0 & 416 & - & 3 \\
\hline POD\#3 & 9.2 & 47.1 & 38.0 & 466 & - & - \\
\hline POD\#4 & 8.2 & 55.1 & 44.0 & 493 & - & - \\
\hline POD\#5 & 9.0 & 51.4 & 37.4 & 472 & - & - \\
\hline POD\#6 & 8.7 & 40.2 & 24.5 & 476 & - & - \\
\hline POD\#7 & 8.0 & 24.5 & 17.1 & 576 & - & - \\
\hline POD\# 8 & 6.4 & 13.9 & 10.0 & - & $1: 2048$ & 1 \\
\hline POD\#9 & 6.8 & 13.6 & 9.2 & - & - & - \\
\hline POD\#10 & 6.3 & 11.3 & 7.8 & - & - & 1 \\
\hline POD\#11 & 7.5 & 15.0 & 9.8 & - & - & - \\
\hline POD\#12 & 5.6 & 10.6 & 6.1 & - & - & - \\
\hline POD\#13 & 5.2 & 8.6 & - & - & - & 1 \\
\hline POD\#14 & 6.2 & 7.1 & 4.4 & 403 & - & - \\
\hline POD\#15 & 5.8 & 6.1 & - & - & - & 1 \\
\hline
\end{tabular}

*Hb: hemoglobin, ${ }^{\dagger}$ LDH: lactate dehydrogenase, ${ }^{\dagger}$ RBC: red blood cell, ${ }^{\S} \mathrm{POD}$ : postoperative day.

was relatively high at $1: 8148$, the reactivity was not high due to the $\mathrm{BT}$ being at $36^{\circ} \mathrm{C}$. The decrease in temperature during the surgery, however, might have caused the hemolytic reaction. It can be assumed that the low temperature (around $20-25^{\circ} \mathrm{C}$ ) decreased the $\mathrm{BT}$ and consequently increased cold agglutinin reactivity. The high activity of cold agglutinin induced the hemolysis, the urine color change, and the high bilirubin level.

Ulvestad et al. [5] reported that hemolysis occurred after infection and trauma in a patient with chronic cold agglutinin disease. The increases in pro-inflammatory cytokines IL-1 $\alpha$, IL6 , TNF- $\alpha$, and IFN- $\gamma$ in response to trauma can cause both an increase in BT and complement-mediated hemolysis, as well as possibly trigger an exacerbation of hemolysis. The patient in this case experienced hemolysis even when a relatively high BT (above $35^{\circ} \mathrm{C}$ ) was maintained during the surgery.

In summary, the maintenance of BT has been regarded as the most important step in the anesthetic management of cold agglutinin disease patients. However, because exposure to a relatively low temperature $\left(25^{\circ} \mathrm{C}\right)$ could modify the cold agglutinin, hemolysis may occur even when the core BT is maintained at around $35.6^{\circ} \mathrm{C}$. During surgery, the urine color must be carefully observed, and hemoglobin, direct bilirubin, and LDH must be measured to monitor for hemolysis.

\section{References}

1. Berentsen S, Beiske K, Tjønnfjord GE. Primary chronic cold agglutinin disease: an update on pathogenesis, clinical features and therapy. Hematology 2007; 12: 361-70.

2. Ulvestad E, Berentsen S, Bo K, Shammas FV. Clinical immunology of chronic cold agglutinin disease. Eur J Haematol 1999; 63: 259-66.

3. Korean agency for technology and standards. Korean standard color book. 2003. Available from http://www.standard.go.kr/KoreaColor/ Color.asp (on 4/07/2013).

4. Berentsen S. How I manage cold agglutinin disease. Br J Haematol 2011; 153: 309-17.

5. Ulvestad E, Berentsen S, Mollnes TE. Acute phase haemolysis in chronic cold agglutinin disease. Scand J Immunol 2001; 54: 239-42. 